
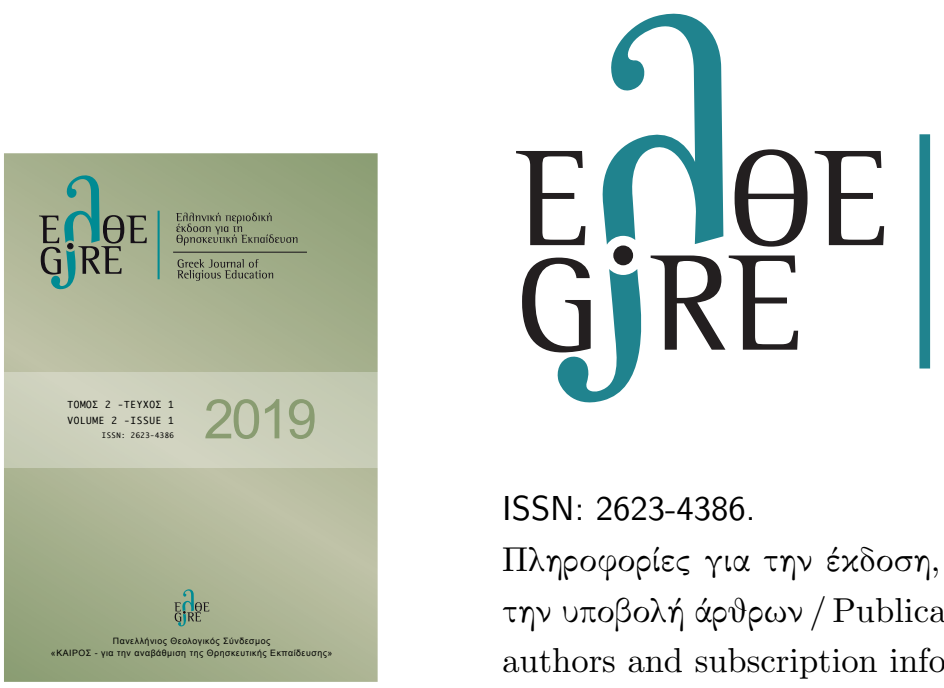

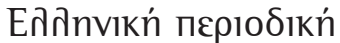

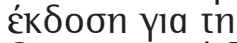

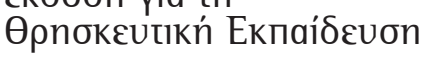

Greek Journal of

Religious Education

ISSN: 2623-4386.

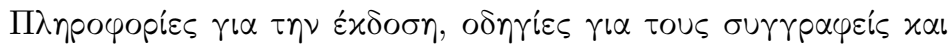

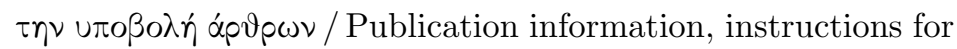
authors and subscription information: http://www.gjre.gr

\title{
Factors shaping prayer frequency among 9- to 11-year-olds
}

Leslie J. Francis*, Tania ap Siôn**, David W. Lankshear***, Emma L. Eccles **** *Professor of Religions and Education, University of Warwick, Coventry, UK

**Senior Post-Doctoral Research Fellow, Bishop Grosseteste University, Lincoln, UK

*** Research Fellow University of Warwick, Coventry, UK

****Research Associate, Bishop Grosseteste University, Lincoln, UK.

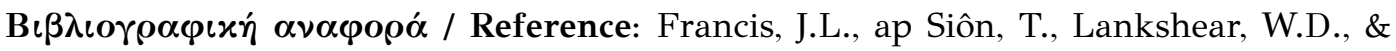
Eccles, L.E. (2019).

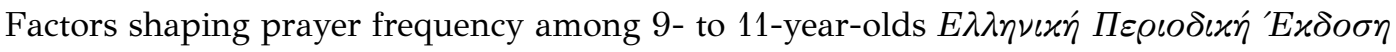

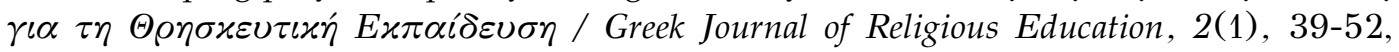
DOI: $10.30457 / 30420193$

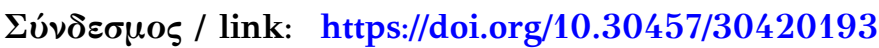

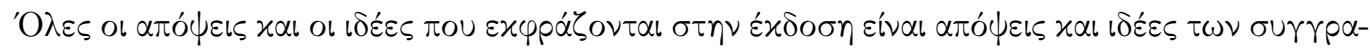

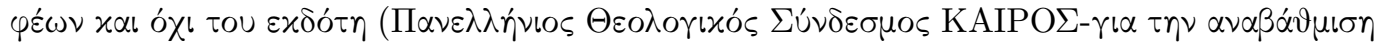

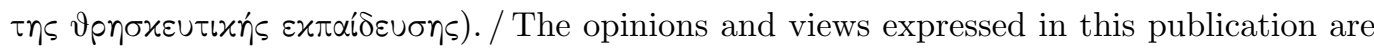
the opinions and views of the authors and not of the publisher (KAIROS - Greek Theological Association for the improvement of the Religious Education).

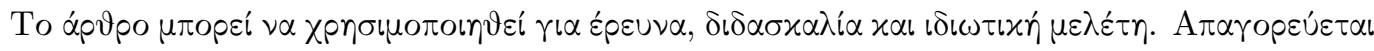

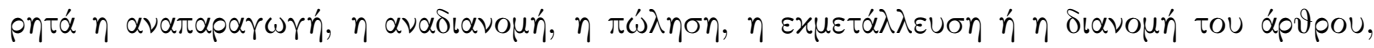

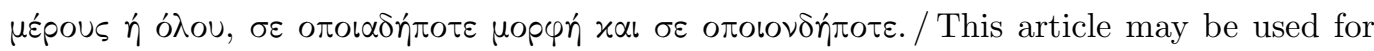
research, teaching, and private study purposes. Any substantial or systematic reproduction, redistribution, reselling, licensing or distribution in any form to anyone is forbidden.

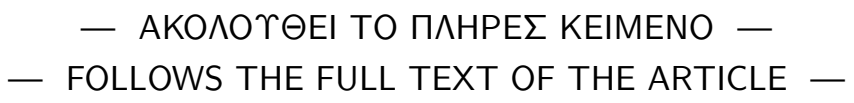




\title{
Factors shaping prayer frequency among 9- to 11-year-olds
}

\author{
Leslie J. Francis* \\ *Professor of Religions and Education, University of Warwick, Coventry, UK \\ Tania ap Siôn** \\ **Senior Post-Doctoral Research Fellow, Bishop Grosseteste University, Lincoln, UK \\ David W. Lankshear*** \\ *** Research Fellow University of Warwick, Coventry, UK \\ Emma L. Eccles **** \\ *****esearch Associate, Bishop Grosseteste University, Lincoln, UK.
}

\begin{abstract}
This paper begins by reviewing the evidence from international research concerning the personal and social correlates of prayer frequency during childhood and adolescence. Overall these data continue to support the view that young people who pray not only report higher levels of personal wellbeing but also report higher levels of pro-social attitudes. These findings raise a research question of particular relelvance within church schools regarding the factors that predict higher levels of prayer activity among students. The Student Voice Project offers data that can illuminate this research question. Among the 3,101 9- to 11-yearold students who participated in the project $11 \%$ prayed daily, $9 \%$ at least once a week, $32 \%$ sometimes, $11 \%$ once or twice a year, and $37 \%$ never. The present paper tests the power of four sets of predictor variables to account for individual differences in prayer frequency among these students: personal factors (age and sex), psychological factors (using the three dimensional model of personality proposed by Eysenck), church attendance (self, mother, and father), and family discussion about prayer (mother, father, and grandparents). Multiple regression analyses identified discussion of prayer with mother as the single most important predictor. These findings locate the development of the practice of prayer within the home, even more than within the church.
\end{abstract}

Key words: psychology of prayer, parental influence, church schools, children.

\section{Introduction}

In the early days of the psychology of religion prayer held a central and important place. For example, William James (1902) spoke of prayer as 'the very soul and essence of religion'; Coe (1916) considered that 'a history and psychology of prayer would be almost equivalent to a history and psychology of religion'; and Hodge (1931) in his book, Prayer and its psychology, argued that 'prayer is the centre and soul of all religion'. By 
the mid-1980s, however, this early focus within the psychology of religion had waned to the point that Finney and Maloney (1985) concluded that:

Nowhere is the long standing breach between psychology and religion more evident than in the lack of research on prayer. Only a few studies of prayer exist inspite of the fact that prayer is of central religious importance.

A similar point was made by other reviews of the literature conducted during the late 1980s, including Hood, Morris, and Watson (1987, 1989); Poloma and Pendleton (1989), and Janssen, de Hart, and de Draak (1989).

A renewed interest in the psychology of prayer was documented and further stimulated during the 1900s and early 2000s by a new generation of studies as illustrated by Brown's (1994) book, The human side of prayer, and by Francis and Astley's (2001) reader, Psychological perspectives on prayer. One particular strand within this re-emerging literature on the psychology of prayer has focused on the place of prayer within the lives of children and young people. This strand has involved both qualitative and quantitative research methods addressing a range of different research questions.

Studies employing qualitative methods have explored: prayer as a positive activity for primary school students (Mountain, 2005); the awareness of connections between positive emotion and prayer and between negative emotion and prayer among 4- to 8-year old children (Bamford \& Lagattuta, 2010); student attitudes to prayer at an American modern Orthodox Jewish high school (Lehmann, 2010); the psychological and spiritual significance of children's prayers from prayer books left in the chapel of a children's hospital (Langford, 2015); the use of prayer among 15-year-old competitive athletes (Hoven \& Kuchera, 2016); the contribution of prayers to shaping literacy within a Catholic primary school (Papen, 2018); and the experiences of students in the implementation of prayer services in religious high schools in Israel (Kohn, 2018).

Studies employing the quantitative methods have explored: the role of prayer in promoting spiritual wellbeing among Pentecostal youth (Tshabalala \& Patel, 2010); the connection between prayer and emotional stability among 15- to 18-year-old students (Pajevic \& Hasanovic, 2014); and the effects of formal instruction on Jewish adolescents' attitudes toward prayer (Sigel, 2016). Quantitative studies concerned with identifying and assessing the antecedents, correlates, and consequences of individual differences in prayer activities or prayer experiences face the added difficulty of differentiating and isolating the effects of prayer from other associated religious practices. In one attempt to bring prayer into sharper focus in such quantitative studies, Francis and colleagues have designed a series of analyses that explore the effects of prayer after controlling for personal factors (age and sex), psychological factors (personality), and public religion engagement (church attendance). Within this series of analyses consistent data reported that young people who prayed displayed a greater sense of purpose in life, a higher level of personal happiness, and greater commitment to pro-social attitudes.

The best documented of these three areas (purpose in life, personal happiness, and pro-social attitudes) concerns research linking prayer frequency with purpose in life, as explored by Francis and Burton (1994), Francis and Evans (1996), Francis (2005), 
Francis and Robbins (2006), and Francis and Penny (2016). For example, Francis and Penny (2016) drew on data provided by 10,792 13- to 15-year-old students from five different parts of the UK (England, Northern Ireland, Scotland, Wales, and London). After controlling for personal factors (age and sex), psychological factors (extraversion, neuroticism, and psychoticism), and religious factors (affiliation and worship attendance), the data demonstrated that prayer frequency added additional prediction of enhanced levels of purpose in life among young people, and that prayer frequency was a stronger predictor of purpose in life than religious affiliation or worship attendance.

Francis and Fisher (2014) explored the connection between prayer and personal happiness, using the Oxford Happiness Inventory proposed by Argyle, Martin, and Crossland (1989). The additional contribution to knowledge made by this study was twofold. The study provided a different conceptualisation of wellbeing (personal happiness in place of purpose in life) and a better established measure of wellbeing (a 29-item measure in place of a single-item index). Drawing on data provided by 1,002 12- to 18-year-old students in Victoria, Australia, this study demonstrated a significant positive correlation between prayer and personal happiness, after taking into account personal factors (age and sex) and psychological factors (extraversion, neuroticism, and psychoticism).

Francis and Robbins (2006) explored the association between prayer and pro-social ttitudes. In this study they employed three six-item measures of pro-social attitudes (attitude toward school, attitude toward law and order, and attitude toward substances). Drawing on data provided by 12,717 13- to 15-year-old students who never attend church, and after controlling for personal factors (age and sex) and psychological factors (extraversion, neuroticism, and psychoticism) this study demonstrated that prayer was associated with higher levels of pro-social attitudes across all three domains, involving a more positive attitude toward school, a more positive attitude toward law and order, and a less positive attitude toward substances.

\subsection{Research question}

In light of the studies that suggest measures of prayer frequency can predict higher levels of wellbeing during childhood and adolescence (purpose in life and personal happiness) and enhanced levels of prosocial attitudes (attitude toward school, attitude toward law and order, and attitude toward substances), the present study proposed to focus on the factors that may predict individual differences in prayer frequency during childhood. Previous research has identified four areas that should be taken into account: personal factors, psychological factors, parental worship attendance, and parental religious engagement.

Personal factors. The two personal factors that routinely predict individual differences in religiosity (including prayer) during childhood and adolescence are sex and age. From the early review of empirical findings within the psychology of religion reported by Argyle (1958), sex differences have been seen as one of the best established findings, at least within Christian and post-Christian contexts: women emerge as more religious than men. Argyle's (1958) conclusion has been confirmed by the more recent review 
reported by Francis and Penny (2014). The decline in religiosity during the years of childhood and adolescence has also been documented by a number of studies and analysed in some depth by Kay and Francis (1996) in their book, Drift from the churches.

Psychological factors. A number of studies have explored the relationship between frequency of personal prayer and personality drawing on Eysenck's dimensional model of personality. Eysenck's model of personality, operationalised by instruments such as the Eysenck Personality Questionnaire (Eysenck \& Eysenck, 1975), the Revised Eysenck Personality Questionnaire (Eysenck, Eysenck, \& Barrett, 1985) and the Eysenck Personality Scales (Eysenck \& Eysenck, 1991), maintains that abnormal personality (poor functional psychological health) is not discrete from, but continuous with, normal personality (good functional psychological health). Accordingly, neurotic disorders lie at one extreme of a dimension of normal personality, ranging from emotional stability, through emotional lability, to neurotic disorder. Similarly, psychotic disorders lie at one extreme of another dimension of normal personality, ranging from tendermindedness, through toughmindedness, to psychotic disorder. Eysenck's model also maintains that the two dimensions of neuroticism and psychoticism are orthogonal and independent of each other. Alongside the measures of neuroticism and psychoticism, Eysenck's model adds a third dimension of personality which is not itself concerned with psychological disorder. This third dimension ranges from introversion, through ambiversion, to extraversion. Eysenck's questionnaires designed to measure these three dimensions of personality also routinely include a lie scale.

An initial study conducted among a sample of 230 16- to 18-year-old female students, reported by Francis and Wilcox (1994), found no significant correlations between prayer frequency and either extraversion scores or neuroticism scores, but a significant negative correlation between prayer frequency and psychoticism scores. In other words, individuals who record low scores on the psychoticism scale are more likely to engage in prayer. This key finding has been supported by studies conducted in the United Kingdom (e.g. Smith, 1996; Francis, Robbins, Lewis, and Barnes, 2008). In the United States of America (Lewis \& Maltby, 1996; Maltby, Talley, Cooper, \& Leslie, 1995; and in Australia (Kaldor, Francis, \& Fisher, 2002).

This established connection between prayer and personality is important to the present enquiry for both conceptual and practical purposes. Conceptually, the connection between prayer and personality is consistent with the implications of Eysenck's dimensional model of personality for explaining individual differences in tenderminded social attitudes in general (Eysenck, 1975, 1976) and in religiosity in particular (Francis, 1992). Practically, the connection between prayer and personality emphasises the importance of taking personality factors into account when constructing a model designed to explore and to explain individual differences in prayer frequency.

Personal worship attendance. A couple of studies in the early 1990s explored the effect of parental worship (or church) attendance on an attitudinal predisposition to pray and on the practice of prayer during childhood and adolescence, employing path analysis that also took into account personal factors (sex), social factors (social class), and contextual factors (type of school). In these two studies attitudinal predisposition to 
pray was assessed by a six-item Likert scale (scored on a five-point rating from disagree strongly, through not certain, to agree strongl), and parental worship attendance was rated by the young participants on a five-point scale of frequency for mothers and for fathers separately. In the first study data were provided by 4,948 11-year-old students in England (Francis \& Brown, 1990). In the second study data were provided by 711 16-year-old students in England (Francis \& Brown, 1991). In both studies parental worship attendance was seen to be a highly significant predictor of child worship attendance and child worship attendance was seen to be a highly significant predictor of prayer frequency. According to this model the effect of parental worship attendance on child prayer frequency was routed via child church attendance. Among the sample of 11-year-old students in addition to this effect routed via child worship attendance there was a further direct effect of parental worship attendance on prayer frequency among young people. Among the sample of 16 -year-old students the whole effect of parental church attendance on child prayer frequency was routed via child church attendance.

Parental religious engagement. While the two studies published by Francis and Brown (1990, 1991) conceptualised parental influence on religious practice (both church attendance and personal prayer) during childhood and adolescence in terms of parental worship attendance, studies conducted as part of (or as influenced by) the Australian National Church Life Survey broadened the research agenda to embrace an examination of other ways in which parents may encourage or nurture religious practices in general among their children. For example, in their report on the survey conducted among 10,101 10- to 14-year-old attenders within the 2001 Australian National Church Life Survey, Bellamy, Mou, and Castle (2005) found that parents have a central role in the development of faith. They concluded that the practice of family prayer times, the encouragement of a personal devotional life for children and parents simply being prepared to talk with their children about faith are all aspects that are positively related to higher levels of belief and a more positive attitude toward and involvement in church life. In their report on the survey conducted among 6,252 8- to 14-year-old attenders within the 2011 Australian National Church Life Survey, Francis, Penny, and Powell (2018) found that these data confirmed the power of parental example on frequency of church attendance. Frequent attendance among young churchgoers occurred when both parents attended as well. The most positive attitude toward their church was found among young churchgoers who had the opportunity to talk about God with their parents and who did not feel that their parents made them go to church. Young churchgoers responded to parental encouragement better than to parental pressure.

\section{Method}

\subsection{Procedure}

All Church in Wales primary schools were invited to participate in a three-year project designed to profile their students experience of and engagement with religious practices, including personal prayer. From the total of 149 Church in Wales primary schools catering for key stage two students across the six Anglican Dioceses (Bangor, Llandaff, Monmouth, St Asaph, St Davids, and Swansea and Brecon), 88 schools participated 
in the student survey conducted during the third year of the project (2016-2017). The schools were asked to administer the questionnaire in normal class groups to all year five (9- to 10-year-old) students and to all year six (10- to 11-year-old) students throughout the school. Students were asked not to write their name on the booklet and to complete the survey without discussing their answers with their peers. They were assured of confidentiality and anonymity. Although students were given the choice not to participate very few declined to do so. All told 3,142 year-five and year-six students participated in the survey.

\subsection{Instrument}

Religious affiliation of students was assessed by the question, 'What sort of place of worship do you go to?' followed by the options: none, Baptist, Church in Wales, Methodist, Pentecostal, Roman Catholic, Presbyterian, Mosque, Synagogue, Gurdwara, Other.

Church attendance of students, mothers, and fathers was assessed by the question: 'Apart from special occasions (like weddings) how often do you /does your mother/does your father attend a place of religious worship (e.g. church, mosque, temple, etc...)? followed by the options: never (1), once or twice a year (2), sometimes (3), at least once a month (4), and weekly (5).

Personal prayer of students was assessed by the question, 'Do you pray when you are on your own?' followed by the options: never (1), once or twice a year (2), sometimes (3), at least once a week (4), and daily (5).

Personality was assessed by the Junior Personality Scales in Three Dimensions (JPS3D: Francis \& Lankshear, in preparation). This instrument proposed three six-item measures of extraversion, emotionality, and toughmindedness. Each item was rated on a five-point Likert scale: disagree strongly (1), disagree (2), not certain (3), agree (4), and agree strongly (5).

Family discussion of prayer was assessed by three items, 'I often talk about prayer with my mother', 'I often talk about prayer with my father', and 'I often talk about prayer with my grandparents'. Each item was rated on a five-point Likert scale: disagree strongly (1), disagree (2), not certain (3), agree (4), and agree strongly (5).

Personal factors were assessed by two dichotomous variables: sex, male (1) and female (2); and school year, year five (1) and year six (2).

\subsection{Participants}

The 3,142 participants comprised 1,585 males and 1,557 females; 1,614 year-five students and 1,528 year-six students. 


\section{Results and discussion}

\subsection{Mapping personal prayer}

Table 1. Frenquecy of personal prayer

\begin{tabular}{cc}
\hline & Self \% \\
\hline Never & 37 \\
Once or twice a year & 11 \\
Sometimes & 32 \\
At least once a week & 9 \\
Daily & 11 \\
\hline
\end{tabular}

Table 1 presents the frequency with which the students reported praying when they are on their own. These data indicated that roughly one in ten students prayed every day (11\%) and that a further one in ten prayed at least once a week (9\%). Slightly more than four in ten prayed sometimes $(32 \%)$ or at least once a year $(11 \%)$. Slightly fewer than four in ten never prayed (37\%).

\subsection{Mapping church attendance}

Table 2. Frenquecy of church attendance

\begin{tabular}{cccc}
\hline & Self \% & Mother \% & Father \% \\
\hline Never & 29 & 47 & 59 \\
Once or twice a year & 14 & 19 & 19 \\
Sometimes & 32 & 19 & 14 \\
At least once a month & 9 & 5 & 3 \\
Weekly & 16 & 10 & 5 \\
\hline
\end{tabular}

Table 2 presents the frequency with which the students, their mothers, and their fathers, attended a place of worship, not including special occasions like weddings. These data indicated that weekly attendance was reported by $16 \%$ of the students, by $10 \%$ of their mothers and by $5 \%$ of their fathers. When weekly attendance and attendance at least once a month were agregated, the data indicated that $25 \%$ of the students, $15 \%$ of their mothers, and $8 \%$ of their fathers attended a place of worship at least once a month. Taking a different perspective, $29 \%$ of the students, $47 \%$ of their mothers, and $59 \%$ of their fathers never attended a place of worship.

\subsection{Mapping family discussion}

\section{Table 3. Discussion about prayer}

\begin{tabular}{cc}
\hline & Yes \% \\
\hline I often talk about prayer with my mother & 23 \\
I often talk about prayer with my father & 16 \\
I often talk about prayer with my grandparents & 20 \\
\hline
\end{tabular}

Note: Yes $=$ sum of agree and agree strongly responses

Table 3 presents the frequency with which the students perceive prayer to be discussed with their family. The data indicate that $16 \%$ of the students consider that they often talk about prayer with their father, and that the proportions rise to $20 \%$ who consider that they often talk about prayer with their grandparents, and to $23 \%$ who consider that they often talk about prayer with their mother. 


\subsection{Testing the measure of personality}

Table 4. Scale properties of personality measure

\begin{tabular}{ccccc}
\hline & N items & alpha & Mean & SD \\
\hline Extraversion & 6 & .66 & 23.86 & 4.10 \\
Emotionality & 6 & .77 & 16.78 & 5.50 \\
Toughmindedness & 6 & .75 & 10.08 & 4.22 \\
\hline
\end{tabular}

Table 4 presents the psychometric properties of the Junior Personality Scales in Three Dimensions (JPS3D), in terms of the alpha coefficients (Cronbach, 1951), the means and the standard deviations. These data indicate satisfactory levels of internal consistency reliability for such short instruments (DeVellis, 2003).

\subsection{Examining correlations}

Table 5. Regression model on student prayer frequency

\begin{tabular}{|c|c|c|c|c|c|}
\hline & $\mathrm{r}$ & Model 1 & Model 2 & Model 3 & Model 4 \\
\hline \multicolumn{6}{|l|}{ Personal factors } \\
\hline sex & $.14^{* * *}$ & $.14^{*+*}$ & $.12^{* * *}$ & $.09^{* * * *}$ & $.09^{* * * *}$ \\
\hline school year & -.03 & -.03 & -.03 & $-.04^{*}$ & -.02 \\
\hline \multicolumn{6}{|l|}{ Psychological factors } \\
\hline extraversion & $.07^{* *}$ & & $.09^{\text {setw }}$ & $.08^{* *}$ & $.04^{*}$ \\
\hline emotionality & .00 & & $.08^{* * * *}$ & $.09^{* * * *}$ & $.07^{* *}$ \\
\hline toughmindedness & $-.11^{* * * *}$ & & $-.12^{* * *}$ & $-.08^{+* * *}$ & $-.06^{* * *}$ \\
\hline \multicolumn{6}{|l|}{ Worship attendance } \\
\hline self & $.39^{* * * *}$ & & & $.20^{0+4}$ & $.13^{* * *+}$ \\
\hline mother & $.41^{*+4+}$ & & & $.18^{* * *}$ & $.10^{*+4 \pi}$ \\
\hline father & $.37^{\text {sot }}$ & & & $.15^{* * *}$ & $.11^{* * *+}$ \\
\hline \multicolumn{6}{|l|}{ Family discussion } \\
\hline mother & $.49^{* * *}$ & & & & $.29^{9 * * *}$ \\
\hline father & $.40^{* * *}$ & & & & -.03 \\
\hline grandparents & $.42^{* * *}$ & & & & $.14^{* * *}$ \\
\hline $\mathrm{R}^{2}$ & & .02 & .04 & .24 & .34 \\
\hline$\Delta \mathrm{R}^{2}$ & & .02 & .02 & .20 & .11 \\
\hline
\end{tabular}

Note: $\quad * * \mathrm{p}<.01 ; * * * \mathrm{p}<.001$

The first column in table 5 presents the bivariate correlations between the students' frequency of prayer and the range of predictor variables assembled in the analysis. These correlations are grouped within four fields of personal factors, psychologicl factors, worship attendance, and family discussion. In terms of personal factors, the correlation coefficients indicate a statistically significant association with sex (females recording a higher level of personal prayer than males), but no significant age effect (comparing year-five with year-six students). In terms of psychological factors, no significant association was found with emotionality, but significant correlations were found with both extraversion and toughmindedness (higher levels of personal prayer were 
reported by those who scored higher on the extraversion scale and lower on the toughmindedness scale). In terms of worship attendance, significant correlations were found with personal worship attendance, mothers' church attendance and fathers' church attendance (higher levels of personal prayer were reported by those who attended church themselves, whose mother attended church, and whose father attended church). In terms of family discussion, significant correlations were found with frequency of discussion with mothers, with fathers, and with grandparents (higher levels of personal prayer are reported by those who often talked about prayer with these members of their family).

\subsection{Examining more correlations}

Table 6. Correlation matrix: Worship and conversation

\begin{tabular}{cllllll}
\hline & Sex & TG & TF & TM & WF & WM \\
\hline Worship self (WS) & $.08^{* * * *}$ & $.29^{* * * *}$ & $.31^{* * *}$ & $.37^{* * * *}$ & $.49^{* * * *}$ & $.62^{* * *}$ \\
Worship mother (WM) & $.07^{* * *}$ & $.29^{* * * *}$ & $.32^{* * *}$ & $.42^{* * *}$ & $.64^{* * *}$ & \\
Worship father (WF) & $.05^{* * *}$ & $.27^{* * *}$ & $.40^{* * *}$ & $.35^{* * *}$ & & \\
Talk mother (TM) & $.05^{* * *}$ & $.68^{* * *}$ & $.77^{* * *}$ & & & \\
Talk father (TF) & $.03^{* * *}$ & $.65^{* * *}$ & & & \\
Talk grandparents (TG) & $.06^{* * * *}$ & & & & \\
\hline
\end{tabular}

Note: ${ }^{* * *} \mathrm{p}<.001$

Examining the correlations with personal prayer one-by-one may disguise the way in which the three components of worship attendance and the three components of family discussion are likely themselves to be highly intercorrelated. Table 6 now presents these intercorrelations together with the effect of sex differences. These data demonstrate the strong correlations between the three variables concerning talking with mother, talking with father and talking with grandparents. Here is clear evidence of the close way in which religion is transmitted within families. Not unsurprisingly there are also strong correlations between parental church attendance and discussions about prayer among family members. Families that talk about prayer also tend to engage in church attendance.

\subsection{Engaging multiple regression}

In order to clarify the complex pattern of associations between worship attendance and discussion about prayer in the home, table 5 also introduces a series of four regression models in which fixed order entry was employed to bring all four sets of variables into consideration. In model one, just personal factors were entered (sex and age). Sex was shown to be significant, but age was not. In model two, psychological factors were added (extraversion, emotionality, and toughmindedness). The introduction of these psychological factors did not disturb the effect of sex, and show that, when considered together all three psychological factors are significant. Higher prayer frequency is assoicated with extraversion, with emotionality, and with tendermindedness. In model three worship attended was added (personal attendance, mothers' attendance and fathers' attendance). All three variables contribute independent predictive power. Higher prayer frequency is associated with the whole family attending church. In model four family discussion was added (talking with mother, talking with father, and talking 
with grandparents). Significant additional variance is explained by adding family discussion. According to this model discussion with mother is particularly important and the importance of discussion with mother is augmented further by discussion with grandparents. Discussion with fathers, however, does not add further effect.

\section{Conclusion}

Recognising that prayer frequency during childhood and adolescence has been shown by previous research to function as a significant predictor of higher levels of personal wellbeing (as assessed by a sense of purpose in life and personal happiness) and of pro-social attitudes (as assessed by attitude toward school, attitude toward law and order, and attitude toward substances), the present study set out to focus on the factors that may predict individual differences in prayer frequency among 9- to 11-year-old students within Church of Wales primary schools. Previous research has identified four areas that should be taken into account: personal factors, psychological factors, parental worship attendance, and parental religious engagement.

In a study conducted among 3,101 students; personal factors were conceptualised in terms of sex and age; psychological factors were conceptualised in terms of extraversion, emotionality, and toughmindedness; worship attendance was conceptualised in terms of self, mother and father; and family religious engagement was conceptualised in terms of conversations about prayer with mother, father and grandparents. Five main conclusions emerge from these new data.

First, when all four factors (personal factors, psychological factors, worship attendance, and family discussion) are considered simultaneously within the same statistical model, the strongest factor in shaping prayer frequency among 9- to 11-year-old students is what happens in the home. Of special importance is conversation with mother alongside conversation with grandparents. Prayer is transmitted inter-generationally when all three generations comprise praying people. The importance of grandparents within this model is significant. Grandparents add statistical weight in addition to the weight carried by parents.

Second, although the bivariate correlations between prayer frequency and family discussions with mother, with father, and with grandparents are all highly significant, within the multiple regression model, the strongest influence within the home in shaping prayer frequency among 9- to 11-year-old students is clearly focused on the mother.

Third, the primary influence of conversation with the mother is not, however, independent of the influence of the father on worship attendance. The regression model confirms that worship attendance is an important predictor of prayer frequency, Moreover, the influence of the church is strongest when the child's church attendance is supported by the attendance of both mother and father.

Fourth, personal factors make a significant contribution to prayer frequency in addition to the effects of worship attendance and support within the family. Girls are more likely to engage in prayer than boys. This finding is consistent with the main body of research within Christian and post-Christian contexts, as documented by Argyle 
(1958), Francis and Penny (2014), and many others.

Fifth, psychological factors make a significant contribution to prayer frequency in addition to the effects of worship attendance, support within the family, and personal factors. All three personality factors have a significant impact. Higher levels of prayer frequency are associated with higher extraversion scores (extraverts are generally more likely to engage in conversation); higher emotionality scores (more anxious and neurotic individuals may be more likely to engage in seeking support); and lower toughmindedness scores (tenderminded individuals are more likely to see the value in religion). These findings are broadly consistent with the body of previous research reviewed in the introduction to this paper.

A major limitation with the present study concerns its focus on and operationalisation of just one aspect of prayer among 9- to 11-year-old students, namely prayer frequency. Although this measure provides good and consistent power (both as a predictor of personal and social correlates of prayer and as a dependent variable indentifying predictors of individual differences in prayer practice), empirical studies concerned with the psychology of prayer have also conceptualised and operationalised richer and better nuanced measures of prayer. Future research in the tradition of the present study could benefit from employing a wider range of measures of prayer.

\subsection{Application}

The findings from the present study may be of interest to churches that share a concern for the transmission of the Christian faith to the current generation of young people growing up in a largely de-churched or unchurched environment. Within the current sample of 3,101 9- to 11-year-old students attending church schools within Wales, around one in ten $(11 \%)$ were growing up with the practice of praying every day; one in ten $(10 \%)$ were living in a household where mother was reported to attend church weekly, and one in twenty (5\%) were living in a household where father was reported to attend church weekly. Those young people who were praying had been influenced by attending church, by attending church with their parents, and by discussing prayer with their parents and with their grandparents; but the most important of these influences was the discussion that goes on across the three generations.

Many of the classic documents of the Catholic Church on Christian education have been clear to stress the collaboration of three core agencies (parents, school, and Church), as documented for example in Gravissimum educationis (Second Vatican Council, 1965). Empirically the primacy among these three core agencies may vary according to the strength of the Christian tradition within the wider society. The present data confirm the view that in largely de-churched or un-churched societies responsibility may fall more heavily on the family when neither schools nor churches may be well equipped to do that job on behalf of Christian parents. If the churches were to recognise this situation and give due weight to it, their primary emphasis within Christian education may need to be oriented toward equipping parents (and grandparents) as effective Christian educators within the home. A good starting point to effect this emphasis may be on strengthening parents' (and grandparents') commitment to be seen as praying people 
and their capacity to engage their children (and grandchildren) both in the practice of prayer and in intelligent conversation about prayer.

\section{References}

Argyle, M. (1958). Religious behaviour. London: Routledge and Kegan Paul.

Argyle, M., Martin, M., \& Crossland, J. (1989). Happiness as a function of personality and social encounters. In J. P. Forgas \& J. M. Innes (Eds.), Recent advances in social psychology: An international perspective (pp. 189-203). Amsterdam, North Holland: Elsevier Science Publishers.

Bamford, C., \& Lagattuta, K. H. (2010). A new look at children's understanding of mind and emotion: The case of prayer. Developmental Psychology, 46(1), 78-92. doi.org/10.1037/a0016694

Bellamy, J., Mou, S., \& Castle, K., (2005). Survey of church attenders aged 10- to 14-years: NCLS Occasional Paper. Sydney, New South Wales: NCLS Research.

Brown, L. B. (1994). The human side of prayer: The psychology of praying. Birmingham, AL: Religious Education Press.

Coe, G. A. (1916). The psychology of religion. Chicago, IL: University of Chicago Press.

Cronbach, L. J. (1951). Coefficient alpha and the internal structure of tests. Psychometrika, 16(3), 297-334. doi.org/10.1007/BF02310555

DeVellis, R. F. (2003). Scale development: Theory and applications. London: Sage.

Eysenck, H. J. (1975). The structure of social attitudes. British Journal of Social and Clinical Psychology, 14(4),323-331. doi.org/10.1111/j.2044-8260.1975.tb00188.x

Eysenck, H. J. (1976). Structure of social attitudes. Psychological Reports, 39(1), 463-466. doi.org/10.2466/ pr0.1976.39.2.463

Eysenck, H. J., \& Eysenck, S. B. G. (1975). Manual of the Eysenck Personality Questionnaire (adult and junior). London: Hodder and Stoughton.

Eysenck, H. J., \& Eysenck, S. B. G. (1991). Manual of the Eysenck Personality Scales. London: Hodder and Stoughton.

Eysenck, S. B. G., Eysenck, H. J., \& Barrett, P. (1985). A revised version of the psychoticism scale. Personality and Individual Differences, 6(1), 21-29. doi.org/10.1016/0191-8869(85)90026-1

Finney, J. R., \& Malony, H. N. (1985). Empirical studies of Christian prayer: A review of the literature. Journal of Psychology and Theology, 13(2), 104-115. doi.org/10.1177/009164718501300203

Francis, L. J. (1992). Is psychoticism really a dimension of personality fundamental to religiosity? Personality and Individual Differences, 13(6), 645-652. doi.org/10.1016/0191-8869(92)90235-H

Francis, L. J. (2005). Prayer, personality and purpose in life among churchgoing and non-churchgoing adolescents. In L. J. Francis, M. Robbins, \& J. Astley (Eds.), Religion, education and adolescence: International empirical perspectives (pp. 15-38). Cardiff: University of Wales Press.

Francis, L. J., \& Astley, J. (Eds.) (2001). Psychological Perspectives on Prayer: A reader. Leominster: Gracewing.

Francis, L. J., \& Burton, L. (1994). The influence of personal prayer on purpose in life among Catholic adolescents. Journal of Beliefs and Values, 15(2), 6-9. doi.org/10.1080/1361767940150202 
Francis, L. J., \& Brown, L. B. (1990). The predisposition to pray: A study of the social influence on the predisposition to pray among eleven year old children in England. Journal of Empirical Theology, 3(2), 23-34. doi.org/10.1163/157092590X00101

Francis, L. J., \& Brown, L. B. (1991). The influence of home, church and school on prayer among sixteen year old adolescents in England. Review of Religious Research, 33(2), 112-122. doi.org/10.2307/3511908

Francis, L. J., \& Evans, T. E. (1996). The relationship between personal prayer and purpose in life among churchgoing and non-churchgoing 12-15 year olds in the UK. Religious Education, 91(1), 9-21. doi. org/10.1080/0034408960910102

Francis, L. J., \& Fisher, J. W. (2014). Prayer and personal happiness: A study among secondary school students in Australia. Journal of Religious Education, 62(1), 79-86. doi.org/10.1007/s40839-014-0010-5

Francis, L. J., \& Lankshear, D.W. (in preparation). Introducing the JPS3D: Junior Personality Scales in Three Dimensions (extraversion, emotionality, and toughmindedness).

Francis, L. J., \& Penny, G. (2014). Gender differences in religion. In V. Saroglou (Ed.). Religion, personality and social behaviour (pp. 313-337). New York. Psychology Press.

Francis, L. J., \& Penny, G. (2016). Prayer, personality and purpose in life: An empirical enquiry among adolescents in the UK. Research in the Social Scientific Study of Religion, 27, 192-209.

Francis, L. J., Penny, G., \& Powell, R. (2018). Assessing peer and parental influence on the religious attitudes and attendance of young churchgoers: Exploring the Australian National Church Life Survey. Journal of Beliefs and Values, 39(1), 57-72. doi.org/10.1080/13617672.2016.1209923

Francis, L. J., \& Robbins, M. (2006). Prayer, purpose in life, personality and social attitudes among nonchurchgoing 13- to 15-year-olds in England and Wales. Research in the Social Scientific Study of Religion, 17, 123-155.

Francis, L. J. Robbins, M., Lewis, C. A. \& Barnes, L. P. (2008). Prayer and psychological health: A study among sixth-form pupils attending Catholic and Protestant schools in Northern Ireland. Mental Health, Religion and Culture, 11(1), 85-92. doi.org/10.1080/13674670701709055

Francis, L. J., \& Wilcox, C. (1994). Personality, prayer and church attendance among 16- to 18-year-old girls in England. Journal of Social Psychology, 134(2), 243-246. doi.org/10.1080/00224545.1994.9711388

Hodge, A. J. (1931). Prayer and its psychology. London: SPCK.

Hood, R. W., Morris, R. J., \& Watson, P. J. (1987). Religious orientation and prayer experience. Psychological Reports, 60, 1201-1202. doi.org/10.2466/pr0.1987.60.3c.1201

Hood, R. W., Morris, R. J., \& Watson, P. J. (1989). Prayer experience and religious orientation. Review of Religious Research, 31(1), 39-45. doi.org/10.2307/3511022

Hoven, M., \& Kuchera, S. (2016). Beyond tebowing and superstitions: Religious practices of 15-year-old competitive athletes. International Journal of Children's Spirituality, 21(1), 52-65. doi.org/10.1080/1364 436X.2016.1150814

James, W. (1902). The varieties of religious experience. New York: Longmans Green. doi.org/10.1037/10004-000

Janssen, J., de Hart, J., \& de Draak, C. (1989). Praying practices. Journal of Empirical Theology, 2(1), 28-39. doi.org/10.1163/157092589X00103

Kaldor, P., Francis, L. J., \& Fisher, J. W. (2002). Personality and spirituality: Christian prayer and Eastern meditation are not the same. Pastoral Psychology, 50, 165-172. doi.org/10.1023/A:1012944603577

Kay, W. K., \& Francis, L. J. (1996). Drift from the Churches: Attitude toward Christianity during childhood and 
adolescence. Cardiff: University of Wales Press.

Kohn, E. (2018). Prayer services in Jewish religious high schools for boys in Israel: Students' perspectives. Greek Journal of Religious Education, 1(1), 24-40. doi.org/10.30457/031020183

Langford, L. (2015). Children's prayers from a hospital chapel. International Journal of Children's Spirituality, 20(3/4), 178-190. doi.org/10.1080/1364436X.2015.1086729

Lehmann, D. (2010). Student and teacher responses to prayer at a modern Orthodox Jewish high school. Religious Education, 105(3), 299-316. doi.org/10.1080/00344081003772063

Lewis, C. A., \& Maltby, J. (1996), Personality, prayer, and church attendance in a sample of male college students in the USA. Psychological Reports, 78, 976-978. doi.org/10.2466/pr0.1996.78.3.976

Maltby, J., Talley, M., Cooper, C., \& Leslie, J. C. (1995). Personality effects in personal and public orientations toward religion. Personality and Individual Differences, 19(2), 157-163. doi.org/10.1016/01918869(95)00036-6

Mountain, V. (2005). Prayer is a positive activity for children: A report on recent research. International Journal of Children's Spirituality, 10(3), 291-305. doi.org/10.1080/13644360500347573

Pajevic, I., \& Hasanovic, M. (2014). Prayer as preventing factor of social excluding of young people. European Psychiatry, 29(Supplement 1), 1. doi.org/10.1016/S0924-9338(14)77992-1

Papen U. (2018). Hymns, prayers and Bible stories: the role of religious literacy practices in children's literacy learning. Ethnography and Education, 13(1),119-134. doi.org/10.1080/17457823.2016.1277773

Poloma, M. M., \& Pendleton, B. F. (1989). Exploring types of prayer and quality of life: A research note. Review of Religious Research, 31(1), 46-53. doi.org/10.2307/3511023

Second Vatican Council (1965). Gravissimum educationis [Declaration on Christian education]. Retrieved from the Vatican website $26^{\text {th }}$ July 2017: http://www.vatican.va/archive/hist_councils/ii_vatican_council/ documents/vat-ii_decl_19651028_gravissimum-educationis_en.html

Sigel, D. (2016). Prayer and adolescence: Can formal instruction make a difference? Religious Education, 111 (2), 200-221. doi.org/10.1080/00344087.2016.1111042

Smith, D. L. (1996). Private prayer, public worship, and personality among 11-15 year old adolescents. Personality and Individual Differences, 21(6), 1063-1065. doi.org/10.1016/S0191-8869(96)00145-6

Tshabalala, B., \& Patel, C. (2010). The role of praise and worship activities in spiritual well-being: Perceptions of a Pentecostal youth ministry group. International Journal of Children's Spirituality, 15(1), 73-82. doi. org/10.1080/13644361003603074

Leslie J. Francis is Professor of Religions and Education within the Warwick Religions and Education Research Unit, University of Warwick, Coventry, UK.

Tania ap Siôn is Senior Post-Doctoral Research Fellow at Bishop Grosseteste University, Lincoln, UK.

David W. Lankshear is Research Fellow within the Warwick Religions and Education Research Unit, University of Warwick, Coventry, UK.

Emma L. Eccles is Research Associate at Bishop Grosseteste University, Lincoln, UK. 